\title{
Congressional elections
}

All politics is local. (former House Speaker Tip O’Neil)

\section{The Contract with America}

In 1994 the Republican Party led by Newt Gingrich of Georgia in the House and future presidential candidate Bob Dole of Kansas in the Senate celebrated a remarkable victory in the Congressional elections. For the first time since 1955 the Republicans had gained a majority in both chambers of Congress. Indeed it was the first time in that forty-year period that the party had held the House of Representatives at all (see Table 2.1).

Newt Gingrich took much of the credit for the victory. Gingrich was an outspoken conservative who had risen quickly to a position of leadership within the Republican members of the House of Representatives. He was also the central figure behind the Contract with America. The Contract was a manifesto outlining ten key policies which, if a Republican majority were elected, would be brought to the floor of the House for a vote within the first 100 days. It was signed by a significant majority of Republican candidates standing in the House elections and many in the Republican 
Party believed that this document was central to their success in the 1994 elections. It was the first time that so many of the candidates of one party had pledged themselves to a national platform of specific policies which, they argued, offered a sharp contrast to the ability of the previous Democrat Congress to get things done. As we shall see, there is evidence to suggest that they were mistaken in this belief.

\section{Congressional elections}

Elections to Congress are held every two years on the first Tuesday of November, electing the whole of the House and approximately one-third of the Senate each time. House members are elected from constituencies within states containing, on average, around 500,000 voters; Senators represent their entire state. The newly elected members take their seats at the start of the new Congress in January of the following year. In this way while the elections are always held in even-numbered years, each Congress begins and ends in the odd-numbered years.

What made the Contract with America in 1994 such a notable event in the history of Congressional elections is that conventional wisdom considers that local rather than national factors play the greater role in American election campaigns. Voters are assumed to vote as much on the achievements and character of the candidates before them as along a party line. Consequently, candidates run campaigns which stress their personal strengths or their opponent's weaknesses rather than the strengths and weaknesses of the respective parties. Campaign posters ask the public to 'Vote Gingrich' or 'Vote Gephardt' rather than 'Vote Republican' or 'Vote Democrat'. This phenomenon is known as candidate- 
Table 2.1 Party control of the House and Senate since 1945

\begin{tabular}{|c|c|c|c|}
\hline Congress & Year & House & Senate \\
\hline 79th & $1945-47$ & Democrat & Democrat \\
\hline 80th & $1947-49$ & Republican & Republican \\
\hline 81 st & $1949-51$ & Democrat & Democrat \\
\hline $82 \mathrm{nd}$ & $1951-53$ & Democrat & Democrat \\
\hline $83 \mathrm{rd}$ & $1953-55$ & Republican & Republican \\
\hline 84th & $1955-57$ & Democrat & Democrat \\
\hline 85 th & $1957-59$ & Democrat & Democrat \\
\hline 86th & 1959-61 & Democrat & Democrat \\
\hline 87 th & $1961-63$ & Democrat & Democrat \\
\hline 88th & $1963-65$ & Democrat & Democrat \\
\hline 89th & $1965-67$ & Democrat & Democrat \\
\hline 90th & $1967-69$ & Democrat & Democrat \\
\hline 91st & 1969-71 & Democrat & Democrat \\
\hline $92 \mathrm{nd}$ & $1971-73$ & Democrat & Democrat \\
\hline $93 \mathrm{rd}$ & $1973-75$ & Democrat & Democrat \\
\hline 94th & $1975-77$ & Democrat & Democrat \\
\hline 95 th & 1977-79 & Democrat & Democrat \\
\hline 96th & 1979-81 & Democrat & Democrat \\
\hline 97 th & 1981-83 & Democrat & Republican \\
\hline 98th & $1983-85$ & Democrat & Republican \\
\hline 99th & $1985-87$ & Democrat & Republican \\
\hline 100th & 1987-89 & Democrat & Democrat \\
\hline $101 s t$ & 1989-91 & Democrat & Democrat \\
\hline $102 \mathrm{nd}$ & 1991-93 & Democrat & Democrat \\
\hline 103rd & 1993-95 & Democrat & Democrat \\
\hline 104th & 1995-97 & Republican & Republican \\
\hline 105 th & 1997-99 & Republican & Republican \\
\hline 106th & 1999-2001 & Republican & Republican \\
\hline 107 th & 2001-03 & Republican & Democrat* \\
\hline
\end{tabular}

* The 2000 election returned 50 Democrats and 50 Republicans to the Senate, giving the Republicans control of the chamber thanks to the casting vote of Vice-President Cheney. However, in May 2001, Senator Jim Jeffords left the Republicans to become an independent, giving the Democrats control of the Senate. 
centred campaigning. It can be attributed to three characteristics of the American system.

\section{Weak parties}

Compared to the more dominant parties prevalent in Western Europe, American parties appear to be loose ideological groupings of legislators. As will be seen in chapter 5, party leaders in Congress and elsewhere attempt to persuade and cajole their members into voting along party lines. However, they have few sanctions available to force members of Congress to follow a fixed position. Such power would, in fact, be largely undesirable to the parties as they need to allow members the flexibility to act in the way most likely to lead to their re-election.

\section{Varied regional interests}

The sheer size of America and the diversity of its population makes it nearly impossible for a party hoping for nationwide appeal to expect its members to take the same positions on all issues or to have the same policy priorities. A Democrat seeking election from a constituency covering New York City would find it difficult to succeed if she adopted the same policy positions and priorities as a fellow Democrat in, say, rural Kansas. It would be folly for any party to expect candidates to do otherwise.

\section{Primary elections}

Unlike in the United Kingdom, parties in the United States do not have the power to choose who represents them in the elections for Congress. This decision is taken by the voters in each state or district in primary elections. In the months preceding the main Congressional elections, candidates hoping to 
become their party's official nominee, fight other party hopefuls in a primary election. The winner becomes the Democrat or Republican candidate in the general election. In most cases only voters registered as a Democrat or a Republican (on registering to vote Americans can choose to register as a Democrat, a Republican or an Independent) can cast a ballot in the party's primary. These are known as closed primaries. Some areas still hold open primaries, where voters may choose which primary they participate in, regardless of their registered affiliation.

At the start of the twentieth century, primary elections were far from standard across the United States. However, as the years passed, an increasing number of state-level party offices adopted primary elections to choose their candidates. This strengthened the tendency towards candidate-centred campaigns in the subsequent general election; many of the decisions candidates make about their campaign (main policy positions, sources of funding, the staff hired and campaign structures) need to be made early on in the primary campaign. During the primary election, as a candidate's opponents are from the same party, the aim of the campaign is to distinguish the candidate from her challengers, to show why, in ideology or character, she would make a better representative or senator than the other members of her own party. The focus is on the candidate rather than the party. Once the primary election is won, while candidates can change their strategy between the primary and general election, whether to shore up their party's core support or to lure voters away from their opponent, much of their campaign remains based on their own attributes rather than those of their party. 


\section{Who wins?}

There are over 500,000 elected officials in the United States, only 542 of which serve at the federal level: the President and Vice-President of the United States, 100 Senators, 435 Representatives and 5 delegates from the US territories (Puerto Rico, American Samoa, US Virgin Islands and Guam) and Washington DC (delegates can sit in the House of Representatives but are not allowed to vote). Consequently, with so few positions of influence available, competition for election to Congress is intense. Any citizen of the United States who has reached the allotted age (25 for House elections and 30 for the Senate) can stand for election. A candidate wishing to be the nominee of one of the major parties must first win the appropriate primary election or other chosen system of selection in the case of a minor party. Anyone gathering the appropriate number of signatures as established by state law can stand as an independent in the general election. The only further restriction is that a candidate must be a resident of the state they are hoping to represent.

So how does a US citizen improve their chances of being elected to Congress?

\section{Be the Democrat or Republican nominee}

While parties in the United States are less dominant than their counterparts in Western Europe, they still play a fundamental role in American Government. In the modern era nearly all candidates elected to Congress have been the nominee of either the Democrat or Republican Party. Since 1955, only five candidates have been elected to the House or Senate without the nomination of one of the two main parties. There are several reasons for this phenomenon. 
The first reason for the consistent election of one of the two main party candidates is that the parties can provide nominees with the resources and organisation necessary to run an effective campaign. State-level party offices have ready a network of volunteers and contacts to support the party's nominee and they can supply a limited amount of campaign funds. Most crucially, the candidate can run under the banner of the official Republican or Democrat Party. Except where there is a notable independent candidate, the two major party nominees will receive far more media coverage than any third party campaign. In many ways this is a self-perpetuating trend; the media, wanting to focus on campaigns of the serious contenders will turn to the major party candidates, not because they are better people or more able campaigners than any independent, but because the candidate with a major party label is usually the winner. This perception is relayed to the public via increased media coverage. The majority of voters, not wishing to waste their vote on a no-hoper will be drawn to the Democrat or Republican candidate. The perception that major party candidates are the only viable ones is reinforced by the resources parties can supply candidates with.

Even with a rise in the number of voters considering themselves politically independent, the majority of Americans still view themselves, to varying degrees, Democrat or Republican. Table 2.2 shows the changes in party identification among the electorate (1952-98). While candidates cannot assume that a voter identifying with their party will automatically vote for them in the election, it is clear that as long as voters perceive electoral politics essentially as a choice between Democrats and Republicans, those parties' candidates will have an enormous advantage over most independents at election time. 
Table 2.2 Party identification 3-point scale 1952-98. Generally speaking, do you usually think of yourself as a Republican, a Democrat, an Independent, or what?

\begin{tabular}{|c|c|c|c|c|c|c|c|c|c|c|c|c|c|c|c|c|c|c|c|c|c|c|c|c|}
\hline ear & 52 & '54 & '56 & 58 & '60 & '62 & '64 & '66 & '68 & 70 & '72 & ’74 & '76 & '78 & '80 & '82 & '84 & '86 & '88 & 90 & '92 & '94 & '96 & \\
\hline & 57 & 56 & 50 & 56 & 52 & 54 & 61 & 55 & 55 & 54 & 52 & 52 & 52 & 54 & 52 & 55 & 48 & 51 & 47 & 52 & 50 & 47 & 52 & 51 \\
\hline ndependent (\%) & 6 & 7 & 9 & 7 & 10 & 8 & 8 & 12 & 11 & 13 & 13 & 15 & 15 & 14 & 13 & 11 & 11 & 12 & 11 & 10 & 12 & 11 & 9 & \\
\hline & 34 & 33 & 37 & 33 & 36 & 35 & 30 & 32 & 33 & 32 & 34 & 31 & 33 & 30 & 33 & 32 & 39 & 36 & 41 & 36 & 38 & 41 & 38 & 37 \\
\hline Apolitical (\%) & 3 & 4 & 4 & 4 & 2 & 4 & 1 & 1 & 1 & 1 & 1 & 3 & 1 & 3 & 2 & 2 & 2 & 2 & 2 & 2 & 1 & 1 & 1 & \\
\hline
\end{tabular}

Source: The National Election Studies. 


\section{Be the incumbent}

One of the most striking features of modern Congressional elections is the high number of members of Congress who gain re-election. This is particularly true in the House where the re-election rates frequently exceeded 90 per cent. The factors which explain this trend are known as incumbency advantages.

The first advantage which incumbents have over their challengers in both primary and general elections is that, in the majority of cases, they will be better known than their opponents. While in office incumbents have either two or six years worth of television appearances, public meetings and publicity to get their name and, hopefully, their achievements known. Their opponents will have only months or even weeks to try to gain name recognition.

Incumbents are aided further in the promotion of their name and image by the resources which come with the job. Members of Congress have a sizeable staff in both Washington DC and their home-state offices. While challengers will have to find money for items such as stationary and postage costs, the Government provides this for members of Congress. The franking privilege (the ability to send mail to constituents free of charge) designed to allow members of Congress to keep their constituents informed of the actions of their representatives, has often caused controversy. The law states that the franking privilege cannot be used for the purpose of electioneering or sending any mail which 'specifically solicits political support for the sender or any other person or any political party, or a vote or financial assistance for any candidate for any public office'. ${ }^{1}$ However, as critics point out, the difference between a letter informing constituents of what their representative has been doing on their behalf and one 
'soliciting political support' can be fine indeed. It is noticeable that those incumbents facing the closest election battles are often the ones who use the privilege most. ${ }^{2}$

Incumbents have a number of other institutional advantages over their opponents, including government-subsidised travel between the constituency and the Capitol and radio and television facilities in Congress which allow members to appear on local media while in Washington. However, perhaps the greatest advantage incumbents possess is that they can actually do the job. Representatives have two and Senators have six years during which to impress their constituents. As will be discussed in chapter 3, members try to pass legislation or take policy positions in speeches which will win the favour of their constituents and they attempt to ensure that any programme distributing grants or other benefits includes their own state or district (and their role in obtaining benefits well publicised). Even more important is the part of the job known as constituency service, which entails responding to the queries, complaints or problems of individual constituents. Addressing the concerns of individual voters may seem a fruitless task in a nation as large as the United States, but as former House Speaker Tip O’Neil explained

A politician learns that if a constituent calls about a problem, even if it's a streetlight out, you don't tell them to call City Hall. You call City Hall. Members of the House learn this quicker than anyone else because they only have a two-year term. They learn that if you don't pay attention to the voters, you soon will find yourself right back there with them. ${ }^{3}$

The decline of party identification in the modern era has made such personal advantages even more important. With Republican and Democrat nominees unable to rely solely on 
their party label, the ability to herald their own achievements while in office gives any incumbent a head start over their often less experienced challengers.

\section{Spend more money than your opponents}

Running for national office in the United States is an expensive business. In the 2000 Congressional election over $\$ 694$ million was spent by the major party candidates, an increase of 42 per cent from $1998 .{ }^{4}$ The average expenditure of candidates for the House of Representatives was $\$ 474,019$ with their Senate counterparts spending, on average, $\$ 4,787,863$. In the race for the Senate in New Jersey, Democrat Jon Corzine spent over $\$ 54$ million on his campaign alone, compared to the $\$ 4$ million spent by his opponent. Corzine was elected by a margin of 3 per cent.

The cost of running for office can be partly explained by the sheer size of the United States. While candidates for the House of Representatives have on average 500,000 voters to reach, Senate hopefuls often face a potential electorate running into millions. In the 2000 election, candidates running for the Senate in California had a formidable 24 million citizens who were eligible to vote. These potential voters need to be reached by the candidates either in person at rallies and meetings, over the telephone, by mail or through the media of television, radio and newspapers.

While the amount of money a candidate can spend is important in Congressional elections, it is not enough on its own. In the 2000 campaign, Rick Lazio spent over \$33 million, some $\$ 7$ million more than his opponent Hillary Clinton, in the race for the vacant Senate seat for New York. Lazio lost by 12 per cent of the vote. Despite his monetary advantage, Hillary Clinton's high personal profile, mistakes 
by the Lazio campaign and the Democrat vote holding strong, led to Clinton's victory.

Despite such instances, the link between spending power and success is undeniable. In 2000, winning candidates for the House spent, on average, $\$ 653,183$ compared to $\$ 267,145$ for losing major party candidates. In the race for the Senate the figures were $\$ 6,405,755$ and $\$ 3,119,413$, respectively. The differences become even more stark when the closest of races are examined. In races where the winner was elected with 55 per cent of the vote or less, winners spent, on average, 64 per cent more than their nearest competitors.

Matters are further complicated when the amount of money raised and spent by incumbents is examined. In the 2000 House elections incumbents spent nearly three times more, on average, than their challengers; Senate incumbents spent around twice as much as their challengers. In the twenty-nine races where sitting Senators contested their seats, only three were outspent by their challengers. This trend of incumbents achieving a monetary advantage over their opponents can lead us to one of two conclusions: If incumbents are achieving high re-election rates largely due to their institutional advantages (discussed above) and also spend, on average, more money than their challengers, this would suggest a link between the amount of money spent and success in the election, which might not be the complete picture. Alternatively, the spending figures may suggest that one of the reasons incumbents are so successful in gaining re-election is that they can raise and spend more money than their challenger. The reality is probably a combination of both.

Incumbents are able to achieve this spending advantage due to their ability to raise more funds than their opponents. In 2000 House incumbents out-raised their challengers by 
four to one, with their Senate equivalents having a two-to-one advantage. Money for election campaigns usually come from one or more of three sources: the candidate's own pocket,

\section{Box 2.1 Jon Corzine v. Bob Franks, New Jersey Senate 2000}

The 2000 race for the vacant Senate seat in New Jersey was notable for one reason - the record amount of money spent by the eventual winner, Democrat Jon Corzine. The vast majority of Corzine's funds came not from the usual source of Political Action Committees and individual donations but from the multimillionaire candidate himself.

Corzine spending during the general election campaign totalled in excess of $\$ 60$ million, $\$ 3$ million of which was spent on election day alone in an attempt to make sure that Democrat voters went to the polls. A former chairman of investment bank Goldman Sachs and Co., Corzine had amassed his vast fortune on Wall Street. In contrast, the Republican candidate Congressman Bob Franks managed to raise and spend less than a tenth of his opponent's total.

During the campaign, in a state where over half of voters are registered as independents (the rest being equally divided between Democrats and Republicans), Corzine used his fortune to bombard voters with messages advocating increased government support of education and healthcare. His opponent instead focused on the need to root out 'wasteful Washington spending'.

Inevitably attention focused on the money being spent by Corzine. The candidate claimed that his largely self-funded campaign meant that, once elected, he would be indebted to no-one except the voters themselves. The Republicans pointed to the fact that over half of Corzine's $\$ 800$ million wealth was tied up in Goldman Sachs stock, and consequently his former company would 'call his every move'. Corzine promised to liquidate his stock if elected.

Despite the massive imbalance of spending in the campaign, the race was a close one. Corzine won, but only by 51 per cent to 48 per cent of the vote. 
donations by members of the public and contributions from outside groups such as businesses, trade unions and pressure groups. It is the last of these which has caused the most controversy in recent years.

Interest group or business donations are regulated under campaign law dating from the Federal Election Campaign Act of 1971 (amended in 1974 and 1976). Any group wishing to donate money to candidates for federal office must first form a Political Action Committee (PAC) which must be registered with the Federal Election Commission (FEC), the body charged with supervising elections. PACs are limited in how much money they can donate to any one candidate; currently they can give up to $\$ 5,000$ to a single candidate per election (individuals are restricted to donations of $\$ 1,000$ under the same law). The aim of the regulation was to ensure that rich groups, particularly corporations could not attempt to buy undue influence over elected officials. How far this aim has been achieved will be examined in chapter 8 .

Groups donate money to Congressional candidates for two main reasons: to aid the election of candidates sympathetic to their cause (or to aid the defeat of those whose policies they oppose) or to increase the likelihood of having influence over the member of Congress once in office. Both these goals give incumbents a number of advantages when raising funds. The first advantage is that incumbents are in office and can currently influence the workings of Congress, making them a more attractive prospect for a group or company hoping to influence the legislative process through political donations. The second advantage is that incumbents are statistically more likely to gain re-election. Apart from the most principled of groups, PACs are likely to find candidates with a good chance of winning more attractive prospects than a sympathetic outsider. 
In the pursuit of influence, little will be gained from contributing to the funds of losing candidates. This attitude was reflected in the 2000 election when House incumbents, on average, received more than eight times the funds from PACs than did their challengers; for the Senate the advantage was six to one.

As the cost of running a successful campaign increased, the statutory limits on donations by PACs have proven to be only partially successful. Groups and wealthy individuals have managed to find four main ways to circumvent the law. Firstly, services which help the candidate more than would a simple $\$ 1,000$ donation, can be offered free of charge. For example, catering for a fund-raising dinner, transport to move the candidate around the constituency, expensive direct mailing lists provided free of charge. Secondly, PACs engage in what is known as bundling. Rather than donate just the allowed $\$ 5,000$, groups can instead collect the individual $\$ 1,000$ donations of their members and, assuring the FEC that the money comes from individual members rather than the PAC's own funds, present a candidate with a collectively 'bundled' large gift of tens or hundreds of thousands of dollars. Thirdly, due to a Supreme Court ruling designed to protect freedom of speech, any group can spend as much money as they like either promoting or opposing a candidate, as long as there is no contact between the group and any of the candidates in order to co-ordinate their campaign. Finally, in order that the imposed limits do not prevent parties from encouraging a high turnout of voters on election day, the original 1970s law placed no limits on the amount of money which can be donated to local political parties to enable them to 'get out the vote'. Such donations are known as soft money.

Soft money has become a controversial issue in recent elections. The distinction between a party encouraging people to 
come out to vote and encouraging people to come out to vote for their candidate is a fine one. Consequently, donors have been quick to realise that one of the easiest ways to help a candidate is to make a large donation under the soft money law. The issue became a high profile one with Senator John McCain, who lost to George W. Bush in the 2000 Republican Presidential primary elections, placing it firmly on the national agenda. In 2001, McCain, along with Democrat Senator Russ Feingold, introduced legislation to bring soft money under the electoral regulations. After a long and sometimes bitter fight, Congress finally brought soft money under the law. ${ }^{5}$

\section{Run a good campaign}

Money is important for success; indeed without funds for the basics of a campaign victory is unlikely. However, as Rick Lazio discovered in New York, money cannot guarantee a seat in Congress. The characteristics of the local electorate, mood of the electorate nationally, the character and record of the candidates and the strength of their campaigns can all affect the eventual result.

Too often is party overlooked as a factor in elections to Congress. While it is true that the character and campaign of the individual candidate are important to success in elections in the United States, the party still has a large part to play. Republican candidates are regularly more successful than their Democrat challengers in the southern states and rural Midwest, while Democrats often receive in excess of 85 per cent of the African American vote and fare considerably better in urban rather than rural areas. There are still a few constituencies in which one of the two major parties fields candidates unopposed, so small is the chance of the opposing 
party winning the seat. Although part identification has declined in recent years, a vast majority of the population still identify themselves with one of the two major parties to some extent. Most candidates cannot rely solely on their party label for election (and it obviously has no effect in the primary campaign), but the predisposition of the electorate towards one party cannot be ignored in assessing election campaigns.

Coupled with the constituency electorate's party leanings is the effect of national politics on individual campaigns. The conventional wisdom agrees with Tip O'Neil when he states that 'all politics is local', and it is largely right, however national swings for or against one party can also have an effect. One such factor is the performance of the President. Traditionally, during presidential election years, observers believe that a party's performance in the Congressional elections will be affected by the performance of their candidate in the presidential elections. The Congressional party, benefit from the positive feeling towards their presidential candidate, and get pulled along on the successful President's coat-tails.

The performance of the winning presidential candidate's Congressional party in presidential election years is shown in Table 2.3a. Since 1948, while the winning Presidential candidate's party has often had success in that year's Congressional election, one is no guarantee of the other. Indeed in the last four elections the party which won the race for the White House has actually lost seats in the House of Representatives. One reason for this trend has been the growth of split-ticket voting, where voters vote for different parties for President and Congress in the same year.

Perhaps more notable are the results of the mid-term elections which take place between Presidential elections. As shown in Table 2.3b, the party which holds the White House 
Table 2.3a The coat-tails effect?

\begin{tabular}{lllcc}
\hline Year & $\begin{array}{l}\text { Winning } \\
\text { presidential } \\
\text { candidate }\end{array}$ & $\begin{array}{l}\text { Winning } \\
\text { presidential } \\
\text { candidate's } \\
\text { party }\end{array}$ & $\begin{array}{c}\text { Performance of winning } \\
\text { presidential candidate's } \\
\text { party (no. of seats) }\end{array}$ \\
\cline { 3 - 5 } & & & $\begin{array}{l}\text { House of } \\
\text { Representatives }\end{array}$ & Senate \\
\hline 1948 & Truman & Democrat & +75 & +9 \\
1952 & Eisenhower & Republican & +22 & +1 \\
1956 & Eisenhower & Republican & -2 & No change \\
1960 & Kennedy & Democrat & -21 & No change \\
1964 & Johnson & Democrat & +37 & +1 \\
1968 & Nixon & Republican & +5 & +6 \\
1972 & Nixon & Republican & +12 & -2 \\
1976 & Carter & Democrat & +1 & No change \\
1980 & Reagan & Republican & +34 & +12 \\
1984 & Reagan & Republican & +15 & -1 \\
1988 & Bush (G.) & Republican & -2 & No change \\
1992 & Clinton & Democrat & -18 & -1 \\
1996 & Clinton & Democrat & +9 & -4 \\
2000 & Bush (G.W.) & Republican & -1 & \\
\hline
\end{tabular}

tend to lose seats in Congress. Indeed, in all post-war midterm elections, only once has the President's party not lost seats in the House. This often reflects a general dissatisfaction with the status quo which is usually taken out on the party which holds the White House.

Although national trends and the party leanings of the local electorate have a role to play, candidates for Congress would be unwise to rely purely on their party label to deliver victory in the general election. With the number of people strongly identifying with one of the major parties on the decline, the support of more and more 'floating voters' is there to be won by a good campaign. 
Table 2.3b Mid-term election performance of the President's party

\begin{tabular}{llllc}
\hline Year & President & $\begin{array}{l}\text { President's } \\
\text { party }\end{array}$ & $\begin{array}{l}\text { Performance of the President's } \\
\text { party (no. of seats) }\end{array}$ \\
\cline { 3 - 5 } & & & $\begin{array}{l}\text { House of } \\
\text { Representatives }\end{array}$ & Senate \\
\hline 1950 & Truman & Democrat & -29 & -6 \\
1954 & Eisenhower & Republican & -18 & -1 \\
1958 & Eisenhower & Republican & -49 & -13 \\
1962 & Kennedy & Democrat & -4 & +3 \\
1966 & Johnson & Democrat & -47 & -4 \\
1970 & Nixon & Republican & -12 & +2 \\
1974 & Nixon & Republican & -48 & -5 \\
1978 & Carter & Democrat & -15 & -3 \\
1982 & Reagan & Republican & -26 & +1 \\
1986 & Reagan & Republican & -5 & -8 \\
1990 & Bush (G.) & Republican & -8 & -1 \\
1994 & Clinton & Democrat & -52 & -8 \\
1998 & Clinton & Democrat & +5 & No change \\
\hline
\end{tabular}

By far the largest percentage of a candidate's expenditure goes on their media campaign. With a large electorate to reach with their message, newspapers, radio and television are an essential part of any serious modern Congressional campaign. Focus groups and opinion polls are frequently employed to ensure that the themes of advertising hit home with the public.

The theory in practice

On the surface, the election of 1994 seemed to upset much of the perceived wisdom of how Congressional elections are won and lost. One notable feature was the number of House incumbents who lost their seats in the election. Thirty-four incumbents (all Democrats) lost out to a Republican challenger in the 
general election, the highest figure since 1966. Four Democrats did not even make the general election, being defeated in the primary election before that. Many were replaced by candidates with limited or even no prior political experience. The most significant Democrat incumbent to fall in the general election was Tom Foley of Washington state. What made Foley's defeat stand out was that he was the Speaker of the House of Representatives, making him the biggest scalp the Republicans could claim.

Another feature of 1994 was the sheer size of swing towards the Republicans. The Democrats lost fifty-two seats in the House and eight in the Senate, the highest loss in either chamber since 1946. For the Democrats and President Clinton, 1994 represented an electoral disaster. While commentators had expected Republican gains, few had predicted the size of the landslide which occurred. The frosh class of 1995 (those elected to Congress for the first time in 1994) was unusually large; there were eighty-six in total, of whom seventy-three were Republican, and 90 per cent of those represented constituencies which had returned Democrats to the previous Congress.

The victorious Republicans claimed that the 1994 election defied the conventional wisdom that elections are won and lost on local issues. Republicans said that the election had been 'nationalised' by the Contract with America. By committing the whole House Republican Party to a specific collection of policies, the Republicans not only contrasted themselves from the 'do-nothing' Democrats, but gave the public a clear set of goals by which they could be judged and, ultimately, held accountable. The timing was particularly effective following the failure of President Clinton to pass his promised high profile healthcare reforms despite a Democrat majority 
in both chambers of Congress. Some of the newly elected Republicans saw the Contract as so central to their success that they wore laminated copies of the document around their necks and referred to it as their 'Bible'.

While there is no doubt that the 1994 elections handed the Republican Party a major victory, giving them complete control of Congress for the first time since the 1950s, and the number of Democrat seats which turned Republican was exceptionally large, we should not exaggerate the extent to which it defied previous electoral trends. Although a number of incumbents were defeated, the incumbent re-election rate still reached over 90 per cent in both House and Senate, a higher figure than in the previous election. While an incumbency success rate of 90 per cent is slightly down on the average figure for the 1980s, it is about average for the whole post-war period. Similarly, while the total number of Republican gains was high, it was not unprecedented in midterm elections; losses by one party in the House had reached forty-seven in 1958, 1966 and 1974 and the net gain of eight Senate seats for the Republicans had been equalled by the Democrats in 1986.

As far as the Contract is concerned, the evidence for its central importance to the subsequent electoral success is, at best, shaky. It is probable that the existence of the Contract helped the Republicans' overall image, but awareness of the document appears to be limited outside of the political community. In polls taken at the time, 71 per cent of those questioned had never even heard of the Contract with America, and of those who had, only 7 per cent said it was more likely to make them vote Republican, and 5 per cent claimed that it would actually deter them from supporting the party. Its effect is more likely to have been indirect, ensuring that Republicans 
across the nation campaigned on similar themes, aiding the prominence of these issues in the public's mind. There is evidence that the results of 1994 should be attributed more to the public voting against the Democrats and President Clinton rather than for the Republican agenda. One Republican Representative admitted that not realising this led to mistakes being made. 'When the Republicans held their very first conference after the election, there was a question I was dying to ask. And I've been kicking myself in the butt ever since for not asking it. I wanted to ask, "Did we win or did they lose?",6

The subsequent elections of 1996, 1998 and 2000 followed most of the established electoral trends. Incumbency re-election rates remained around 90 per cent and there were no dramatic shifts in the party balance in either chamber. The Democrats did buck the trend by picking up seats at the 1998 mid-term elections, despite a Democrat incumbent in the White House. Overall, the traditional wisdom as to how campaigns are run, won and lost remains valid.

\section{Summary}

Elections to Congress are determined more by local issues and personality than any equivalent election in Western Europe. Such factors have been made even more central by the growth of primary elections to determine the nominees of the major parties. The ability to raise and spend significant amounts of money has also become an important determinant of electoral success. In addition, incumbents hold a large advantage over challengers, with re-election rates consistently reaching over 90 per cent. Despite this, the importance of the party should not be overlooked. The 1994 Congressional elections 
saw the Republicans take control of the House of Representatives and Senate for the first time since the 1952 election. Claims have been made that this success was due to the Contract with America which pledged Republican candidates to a national manifesto of policy pledges, although the evidence suggests that other factors were more important.

\section{Notes}

1 US Code, 39 USC Sec. 3210 (5C).

2 G. R. Simpson, 'Surprise! Top Frankers Also Have the Stiffest Challenges', Roll Call (22 October 1992) pp. 1, 15.

3 T. O'Neil, All Politics is Local (Holbrook MA: Bob Adams Inc., 1994) p. xvi.

4 Source: Common Cause (www.commoncause.org) and Federal Election Commission (www.fec.gov).

5 However, at the time of writing, there is still a chance that this law may be subject to a challenge in the courts.

6 Quoted in R. F. Fenno, Learning to Govern: An Institutional View of the 104th Congress (Washington DC: Brookings Institution Press, 1997), p. 30. 